\title{
POLITIK HUKUM PERSAINGAN USAHA DI INDONESIA
}

\section{Muhammad Fajar Hidayat}

\author{
Dosen Program Studi Ilmu Hukum Universitas Maritim Raja Ali Haji (UMRAH) \\ dan Anggota Forum Dosen Persaingan Usaha (FDPU) \\ Jalan Raya Dompak, Pulau Dompak, Tanjungpinang 29125, Indonesia \\ Penyesuaian Pengarang E-mail: muhammad.fajar.hidayat@gmail.com
}

No. Hp: +6281365661902

\begin{abstract}
ABSTRAK
Sebagai reaksi terhadap maraknya kegiatan konglomerasi, sejak tahun 1980'an di Indonesia, masyarakat selanjutnya menuntut dikeluarkannya Undang-Undang Anti Monopoli atau Antitrust Law. Selain itu tuntutan dibuatnya perangkat hukum Anti Monopoli karena terdapat penguasaan bisnis pada sentralisme kekuasaan yang disinyalir kuat mengandung praktik korupsi, kolusi, dan nepotisme (KKN). Adapun yang menjadi tujuan dalam penelitian ini yaitu untuk mengetahui politik hukum persaingan usaha di Indonesia dan yang menyebabkan Undang-Undang Nomor 5 Tahun 1999 tentang Larangan Praktek Monopoli dan Persaingan Usaha Tidak Sehat belum cukup efektif dalam menciptakan persaingan usaha yang sehat di Indonesia. Penulis menggunakan metode penelitian hukum normatif dalam penelitian ini. Hasil penelitian ini menunjukkan bahwa Undang-Undang Nomor 5 Tahun 1999 tentang Larangan Praktek Monopoli dan Persaingan Usaha Tidak Sehat merupakan implementasi dari politik hukum persaingan usaha di Indonesia. Politik hukum persaingan usaha di Indonesia pada prinsipnya tergantung political will dari anggota Dewan Perwakilan Rakyat (DPR) selaku legislatif bersama dengan Pemerintah selaku eksekutif dalam membuat Undang-Undang. Sebab Undang-Undang Nomor 5 Tahun 1999 tentang Larangan Praktek Monopoli dan Persaingan Usaha Tidak Sehat belum cukup efektif dalam menciptakan persaingan usaha yang sehat di Indonesia dikarenakan dalam substansi UU tersebut masih terdapat kelemahan dalam beberapa pasal yang membuat kinerja Komisi Pengawas Persaingan Usaha (KPPU) menjadi tidak maksimal.
\end{abstract}

Kata Kunci: Politik Hukum, Persaingan Usaha dan Pelaku Usaha.

\section{ABSTRACT}

As reaction to its glow conglomeration activity, since year 1980' an at Indonesian, society succeedinging to charge besued Statute Anti Monopoly or Antitrust Law. Besides charge be made peripheral sentences Anti Monopoly because available business mastery on sentralisme power that disinyalir heavy duty contains praktik corruption, kolusi, and nepotism 
$(K K N)$. There is even that as aim in observational it which is to know emulation law politics effort at Indonesian and causative Statute Number 5 Years 1999 about Practice Prohibition Monopolize and Insanitary Effort emulations was enough effective deep create healthy effort emulation at Indonesia. Writer utilizes to methodic normatif's law research in observational it. This observational result points out that Number Law 5 Years 1999 about Practice Prohibition Monopolize and Insanitary Effort emulations constitute implementations of emulation law politicses efforts at Indonesian. Emulations jurisdictional politics effort at Indonesian in principle pending political will of Parliament member (DPR) my interrupts legislative stand up with Government interrupt executive deep legislate. Because Number Law 5 Years 1999 about Practice Prohibition Monopolize and Insanitary Effort emulations was enough effective deep create healthy effort emulation at Indonesia because of in substansi UU that stills to exist weakness in a few section which make emulation Commission performance Effort (KPPU) as is not maximal.

Key word: Jurisdictional politics, Effort emulation and Effort Agent.

\section{PENDAHULUAN}

\section{I.1 Latar Belakang Masalah}

Sebagai reaksi terhadap maraknya kegiatan konglomerasi, sejak tahun 1980'an di Indonesia, masyarakat selanjutnya menuntut dikeluarkannya Undang-Undang Anti Monopoli atau Antitrust Law. Selain itu tuntutan dibuatnya perangkat hukum Anti Monopoli karena terdapat penguasaan bisnis pada sentralisme kekuasaan yang disinyalir kuat mengandung praktik korupsi, kolusi, dan nepotisme (KKN). Secara empiris, masyarakat selama Orde Baru telah mengalami keterbatasan perekonomian (termasuk aspek legalnya) pada praktik bisnis yang penuh keganjilan dan kontradiktif ini (Suyud Margono, 2009: 1). Permasalahan tersebut bagi masyarakat luas menimbulkan ketidakadilan dan berdampak buruk pada kesiapan tata ekonomi nasional yang telah memasuki dan mengikuti perkembangan ekonomi dunia yang akan semakin diwarnai semangat free competition dan seiring dengan semakin 
mengglobalnya ekonomi pasar (Suyud Margono, 2009: 1).

Menurut mantan Ketua Mahkamah Konstitusi (MK) Republik Indonesia yakni Moh. Mahfud MD, politik hukum adalah "legal policy atau garis (kebijakan) resmi tentang hukum yang akan diberlakukan baik dengan perbuatan hukum baru maupun dengan penggantian hukum lama, dalam rangka mencapai tujuan negara" (Moh. Mahfud MD, 2011: 1). Definisi yang sama juga pernah dikemukakan oleh beberapa pakar hukum lainnya. Padmo Wahjono mengatakan bahwa politik hukum adalah kebijakan dasar yang menentukan arah, bentuk, maupun isi hukum yang akan dibentuk (Padmo Wahjono, 1986: 160). Teuku Mohammad Radhie mendefinisikan politik hukum sebagai suatu pernyataan kehendak penguasa negara mengenai hukum yang berlaku di wilayahnya dan mengenai arah perkembangan hukum yang dibangun (Teuku Mohammad Radhie, 1973: 3).

Dalam bukunya yang berjudul "Politik Hukum Menuju Satu Sistem Hukum Nasional", Sunaryati Hartono berpendapat bahwa politik hukum sebagai sebuah alat (tool) atau sarana dan langkah yang dapat digunakan oleh pemerintah untuk menciptakan sistem hukum nasional yang dikehendaki dan dengan sistem hukum nasional itu akan diwujudkan cita-cita bangsa Indonesia (C.F.G. Sunaryati Hartono, 1991: 1). Definisi politik hukum berikutnya dikemukakan oleh Abdul Hakim Garuda Nusantara, dalam sebuah makalahnya yang berjudul "Politik Hukum Nasional” yang disampaikan pada Kerja Latihan Bantuan Hukum (Abdul Hakim Garuda Nusantara, 1985). Menurut Garuda Nusantara, Politik Hukum Nasional secara harfiah dapat diartikan sebagai kebijakan hukum (Legal Policy) yang hendak 
diterapkan atau dilaksanakan secara nasional oleh suatu pemerintahan Negara tertentu. Politik Hukum Nasional bisa meliputi: (1) pelaksanaan ketentuan hukum yang telah ada secara konsisten; (2) pembangunan hukum yang intinya adalah pembaruan terhadap ketentuan hukum yang telah ada dan dianggap usang, dan penciptaan ketentuan hukum baru yang diperlukan untuk memenuhi tuntutan perkembangan yang terjadi dalam masyarakat; penegasan fungsi lembaga penegak atau pelaksana hukum dan pembinaan anggotanya; (4) meningkatkan kesadaran hukum masyarakat menurut persepsi kelompok elit pengambil kebijakan (Imam Syaukani, dkk, 2008: 31).

\section{Mantan Ketua Perancang} Kitab Undang-Undang Hukum Pidana (KUHP) yakni Soedarto mengemukakan bahwa politik hukum adalah kebijakan negara melalui badan-badan negara yang berwenang untuk menetapkan peraturan-peraturan yang dikehendaki yang diperkirakan akan dipergunakan untuk mengekspresikan apa yang terkandung dalam masyarakat dan untuk mencapai apa yang dicitacitakan (Soedarto, 1979: 15-16). Menurut Abdul Latif, politik hukum adalah kebijakan dasar penyelenggara negara dalam bidang hukum yang akan, sedang dan telah berlaku, yang bersumber dari nilai-nilai yang berlaku di masyarakat untuk mencapai tujuan negara yang dicita-citakan (Abdul Latif, dkk, 2010: 27).

Guru Besar yang sangat terkenal dari Fakultas Hukum Universitas Diponegoro (UNDIP) yakni Satjipto Rahardjo mendefinisikan politik hukum sebagai aktifitas memilih dan cara yang hendak dipakai untuk mencapai suatu tujuan sosial dengan hukum tertentu di dalam masyarakat yang cakupannya 
meliputi jawaban atas beberapa pertanyaan mendasar, yaitu, 1) tujuan apa yang hendak dicapai melalui sistem yang ada; 2) caracara apa dan yang mana yang dirasa paling baik untuk dipakai dalam mencapai tujuan tersebut; 3) kapan waktunya dan melalui cara bagaimana hukum itu perlu diubah; 4) dapatkah suatu pola yang baku dan mapan dirumuskan untuk membantu dalam memutuskan proses pemilihan tujuan serta cara-cara untuk mencapai tujuan tersebut dengan baik (Satjipto Rahardjo, 1991: 352-353). Menurut Bernard L. Tanya, politik hukum adalah menyangkut cita-cita/harapan, maka harus ada visi terlebih dahulu. Visi hukum, tentu harus ditetapkan terlebih dahulu, dan dalam jalur visi itulah bentuk dan isi hukum dirancang-bangun untuk mewujudkan visi tersebut. Dengan kata lain, politik hukum tidak boleh terikat pada "apa yang ada", tetapi harus mencari jalan keluar kepada "apa yang seharusnya". Oleh karena itu, keberadaan politik hukum ditandai oleh tuntutan untuk memilih dan mengambil tindakan (Bernard L. Tanya, 2011: 3).

Guru Besar Hukum Tata Negara Universitas Padjadjaran (UNPAD) yakni Bagir Manan berpendapat bahwa politik hukum dapat bersifat tetap (permanen) dan temporer. Politik hukum yang bersifat permanen berkaitan dengan sikap hukum yang akan selalu menjadi dasar kebijaksanaan pembentukan dan penegakan hukum; misalnya terdapatnya satu sistem hukum nasional dengan adanya unifikasi hukum atau berlakunya satu sistem hukum di seluruh wilayah Indonesia. Di samping itu, masyarakat juga memiliki peran yang sangat penting dalam pembentukan hukum; seperti hukum adat dan hukum yang tidak tertulis lainnya yang diakui sebagai sub sistem hukum nasional sepanjang nyata- 
nyata hidup dan dipertahankan dalam pergaulan masyarakat. Sedangkan politik hukum yang bersifat temporer adalah kebijaksanaan yang ditetapkan dari waktu ke waktu sesuai dengan kebutuhan (Kotan Y. Stefanus).

Secara umum, hukum persaingan usaha bertujuan untuk menjaga "iklim persaingan" antar pelaku usaha serta menjadikan persaingan antar pelaku usaha menjadi sehat (Mustafa Kamal Rokan, 2010: 20). Selain itu, hukum persaingan usaha bertujuan menghindari terjadinya eksploitasi terhadap konsumen oleh pelaku usaha tertentu serta mendukung sistem ekonomi pasar yang dianut oleh suatu negara. Tujuan hukum persaingan usaha di Indonesia menurut Pasal 3 UU No. 5 Tahun 1999 adalah :

1. Menjaga kepentingan umum dan meningkatkan efisiensi ekonomi nasional sebagai salah satu upaya untuk

meningkatkan

kesejahteraan rakyat;

2. Mewujudkan iklim usaha yang kondusif melalui peraturan persaingan usaha yang sehat, sehingga menjamin adanya kepastian kesempatan berusaha yang sama bagi pelaku usaha besar, pelaku usaha menengah, dan pelaku usaha kecil;

3. Mencegah praktik monopoli dan/atau persaingan usaha tidak sehat yang ditimbulkan pelaku usaha; dan

4. Tercitanya efektivitas dalam kegiatan usaha. Berdasarkan latar belakang di atas, penulis tertarik untuk mengkaji lebih lanjut dalam sebuah penelitian yang berjudul "Politik Hukum 
Persaingan Usaha di

Indonesia".

\subsection{Rumusan Masalah}

Berdasarkan latar belakang penelitian di atas, maka rumusan masalah dalam penelitian ini yaitu:

1. Bagaimanakah politik hukum persaingan usaha di Indonesia?

2. Apakah yang menyebabkan UndangUndang Nomor 5 Tahun 1999 tentang Larangan Praktek Monopoli dan Persaingan Usaha Tidak Sehat belum cukup efektif dalam menciptakan persaingan usaha yang sehat di Indonesia?

\section{METODE PENELITIAN}

\subsection{Desain Penelitian}

Penelitian yang dilaksanakan adalah penelitian hukum normatif. Penelitian hukum normatif adalah penelitian hukum yang meletakkan hukum sebagai sebuah bangunan sistem norma (Mukti Fajar ND dan Yulianto Achmad, 2010: 34). Sistem norma yang dimaksud adalah mengenai asas-asas, norma, kaidah dari peraturan perundangundangan, putusan pengadilan, perjanjian serta doktrin (ajaran). Peter Mahmud Marzuki menjelaskan penelitian hukum normatif adalah suatu proses untuk menemukan suatu aturan hukum, prinsip-prinsip hukum, maupun doktrin-doktrin hukum untuk menjawab permasalahan hukum yang dihadapi (Peter Mahmud Marzuki, 2005: 35). Soerjono Soekanto dan Sri Mamudji memberikan pendapat penelitian hukum normatif adalah penelitian hukum yang dilakukan dengan cara meneliti bahan pustaka atau data sekunder belaka (Soerjono Soekanto dan Sri Mamudji, 2011: 13). Berbeda dengan pandangan ahli di atas, Sutandyo Wigyosubroto memberikan istilah "penelitian hukum normatif 
dengan istilah penelitian doktrinal, yaitu penelitian terhadap hukum yang dikonsepkan dan dikembangkan atas dasar doktrin yang dianut sang pengonsep atau sang pengembangnya" (Sutandyo Wigyosubroto, 2002: 147-160).

\subsection{Bahan Hukum atau Data Sekunder}

Bahan hukum atau data sekunder dalam penelitian ini yaitu (Soerjono Soekanto, 1986: 52) :

a. Bahan hukum primer, bahan hukum yang terdiri atas peraturan perundangundangan, dalam penelitian ini terdiri dari :

1) Ketetapan MPR RI No. IV/MPR/1973 tentang GBHN bidang Pembangunan

Ekonomi;

2) Ketetapan MPR RI No. IV/MPR/1978 tentang GBHN pada bidang Pembangunan Ekonomi pada Sub Bidang Usaha Swasta dan Usaha Golongan

Ekonomi Lemah;

3) Ketetapan MPR RI No. II/MPR/1983 tentang GBHN pada Bidang Pembangunan Ekonomi Sub Bidang Usaha Swasta Nasional dan Usaha Golongan Ekonomi Lemah;

4) Ketetapan MPR No. II/MPR/1988 tentang GBHN pada Bidang Pembangunan Ekonomi Sub Bidang Dunia Usaha Nasional;

5) Ketetapan MPR RI No. II/MPR/1993 tentang GBHN pada Bidang Pembangunan Ekonomi Sub Bidang Usaha Nasional;

6) Ketetapan MPR RI No. IV/MPR/1999 tentang GBHN pada Kondisi Umum; 
7) Kitab

Undang-

Undang

Hukum

Pidana (KUHP);

8) Kitab

Undang-

Undang

Hukum

Perdata

(KUHPerdata);

9) UU No. 5 Tahun 1960 tentang Peraturan

Dasar Pokok-Pokok Agraria;

10) UU No. 5 Tahun 1984 tentang

Perindustrian;

11) UU No. 19 Tahun 1992 tentang Merek;

12) UU No. 1 Tahun 1995 tentang

Perseroan Terbatas;

13) UU No. 9 Tahun 1995 tentang Usaha Kecil;

14) UU No. 8 Tahun 1995 tentang Pasar Modal;

15) Undang-Undang Nomor 5 Tahun 1999 tentang Larangan

Praktek

Monopoli dan

Persaingan Usaha

Tidak Sehat;

16) PP No. 70 Tahun 1992 tentang Bank Umum;

17) PP No. 27 Tahun 1998 tentang Penggabungan, Peleburan, dan Pengambilalihan Perseroan Terbatas

b. Bahan hukum sekunder, bahan hukum yang terdiri atas buku atau jurnal hukum yang berisi mengenai pandangan para ahli hukum (doktrin) dan hasil penelitian hukum.

\subsection{Metode Pengumpulan Bahan Hukum atau Data Sekunder}

Metode pengumpulan bahan hukum atau data sekunder dalam penelitian ini dilakukan dengan 
cara menginventarisir segala macam peraturan perundangundangan yang ada kaitannya dengan permasalahan yang diangkat dan dengan melakukan studi kepustakaan.

\subsection{Teknik Analisis}

Bahan hukum atau data sekunder yang dipilih melalui studi kepustakaan, kemudian disusun secara sistematis sehingga diperoleh gambaran yang menyeluruh mengenai asas hukum, kaidah hukum, dan ketentuan hokum kemudian dianalisis secara kualitatif dan secara logis serta data yang diperoleh melalui penelitian akan dikaji secara mendalam sebagai suatu kajian yang komprehensif, hasil analisis akan disajikan secara deskriptif analisis.

\section{HASIL PENELITIAN} DAN PEMBAHASAN

\subsection{Hasil Penelitian}

Untuk mengetahui bagaimana jawaban pertanyaan di atas, maka penulis menggunakan asumsi dasar yang menyatakan bahwa hukum adalah produk politik. Pernyataan bahwa "hukum adalah produk politik" adalah benar jika didasarkan pada das Sein dengan mengonsepkan hukum sebagai undang-undang (Moh. Mahfud MD, 2011: 5). Dalam faktanya jika hukum dikonsepkan sebagai undangundang yang dibuat oleh lembaga legislatif maka tak seorang pun dapat membantah bahwa hukum adalah produk politik sebab ia merupakan kristalisasi, formalisasi, atau legalisasi dari kehendak-kehendak politik yang saling bersaingan baik melalui kompromi politik maupun melalui dominasi oleh kekuatan politik yang terbesar. 
Senada dengan pernyataan di atas, tentu saja tidak ada yang bisa menolak bahwa UU No. 5 Tahun 1999 adalah produk politik yang dihasilkan oleh Dewan Perwakilan Rakyat (DPR) bersama dengan Pemerintah. Sebagaimana diketahui, anggota DPR selain merupakan anggota legislatif juga merupakan anggota partai politik, oleh karena itulah tidak mengherankan apapun UU yang dibuat pasti syarat dengan kepentingan politik. Ada 4 (empat) pengaruh politik terhadap kekuatan hukum yaitu sebagai berikut (Abdul Latif, dkk, 2010: 172-173) :

1. Pertama, adalah jelas bahwa politik mempunyai dampak terhadap hukum. Kedua aspek kehidupan (politik dan hukum) tersebut terlihat dari kenyataan bahwa hukum merupakan produk dari proses politik tanpa perlu membedakan apakah proses tersebut diolah para pemeran politik yang mempunyai kekuatan berimbang atau dijalankan melalui dominasi suatu pihak.

2. Kedua, dalam setiap titik pertemuan politik dengan hukum tersebut terdapat dua kemungkinan dampak politik terhadap hukum, yaitu peluang bagi pertumbuhan hukum atau mempengaruhinya secara negatif baik dalam bentuk menghambat pertumbuhannya maupun memperlemah kekuatannya.

3. Ketiga, perjalanan kehidupan politik bangsa Indonesia ditandai oleh peningkatan kesenjangan peranan politik elit (penguasa) dengan masyarakat dan 


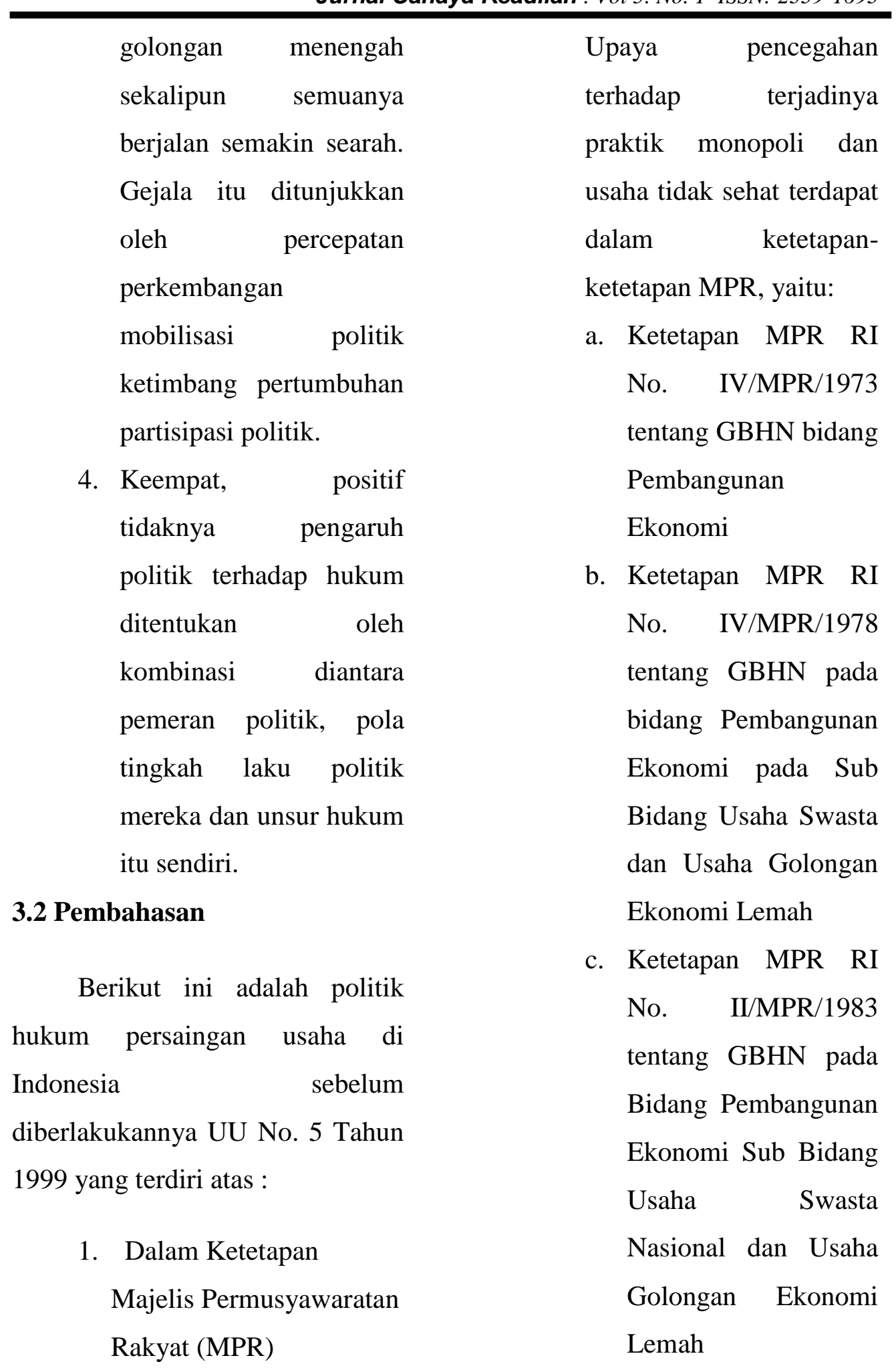


d. Ketetapan MPR No.

II/MPR/1988 tentang

GBHN pada Bidang

Pembangunan

Ekonomi Sub Bidang

Dunia Usaha Nasional

e. Ketetapan MPR RI

No. II/MPR/1993 tentang GBHN pada

Bidang Pembangunan

Ekonomi Sub Bidang

Usaha Nasional

f. Ketetapan MPR RI

No. IV/MPR/1999

tentang GBHN pada

Kondisi Umum

(Susanti Adi

Nugroho, 2001: 15).

2. Pasal 383 bis W.V.S.

(KUHP) yang berbunyi:

"Barangsiapa

mendapatkan,

melangsungkan atau

memperluas hasil

perdagangan atau

perusahaan milik sendiri

atau orang lain, melakukan perbuatan curang untuk menyesatkan khalayak umum atau seseorang tertentu, diancam karena persaingan curang dengan pidana paling lama satu (1) tahun empat bulan atau denda paling banyak Rp. 13.500,00 jika hal itu menimbulkan kerugian bagi saingannya sendiri atau saingan orang lain."

3. Pasal 1365

KUHPerdata berbunyi:

"Setiap perbuatan yang melanggar hukum dan membawa kerugian kepada orang lain, mewajibkan orang yang menimbulkan suatu kerugian tersebut karena kesalahannya untuk mengganti kerugian tersebut."

4. UU No. 5 Tahun 1960

tentang Peraturan Dasar

Pokok-Pokok Agraria

Pada Pasal 13 ayat (2)

UU No. 5 Tahun 1960

menentukan pemerintah

harus mencegah usaha-

usaha dari organisasi-

organisasi dan

perseorangan yang

bersifat monopoli

swasta. Dalam ayat 3 
disebutkan

bahwa

monopoli pemerintah

dalam lapangan agraria

dapat diselenggarakan

asal

dilakukan

berdasarkan UU.

5. UU No. 5 Tahun 1984

tentang Perindustrian

yang berbunyi:

"Dalam Pasal 7 memuat ketentuan tentang kewenangan pemerintah untuk melakukan pengaturan, pembinaan, dan pengembangan terhadap industri untuk: (1) mewujudkan pengembangan industri yang lebih baik, secara sehat dan berhasil guna, (2) mengembangkan persaingan yang baik dan sehat serta mencegah persaingan tidak jujur,

mencegah pemutusan atau penguasaan industri oleh satu kelompok atau perorangan dalam bentuk monopoli yang merugikan masyarakat."

6. Pasal 81 dan 82 UU

No. 19 Tahun 1992

tentang Merek

sebagaimana telah diubah menjadi UU No.

14 Tahun 1997

Pasal 81 dan 82 intinya

melarang setiap orang dengan sengaja dan tanpa hak menggunakan merek yang sama dengan merek terdaftar milik orang lain atau milik badan hukum untuk barang dan jasa sejenis yang diproduksi dan atau diperdagangkan.

Menurut Pasal 83 perbuatan yang diatur dalam Pasal 81 dan 82 merupakan kejahatan.

7. UU No. 1 Tahun 1995 tentang Perseroan

Terbatas

Dalam UU No. 1 Tahun 1995 khususnya dalam Bab VII Pasal 102 s/d 109 yang mengatur mengenai penggabungan

(merger), peleburan 
(konsolidasi), dan

pengambilalihan

(akuisisi). Dalam Pasal

104 ayat 1 disebutkan

bahwa penggabungan,

peleburan, dan

pengambilalihan

perseroan harus

memperhatikan:

kepentingan perseroan,

pemegang saham

minoritas, dan

karyawan perusahaan;

(b) kepentingan

masyarakat dan

persaingan sehat dalam

melakukan usaha.

Ketentuan ini

menegaskan bahwa

penggabungan

(merger), peleburan

(konsolidasi), dan

pengambilalihan

(akuisisi) tidak dapat

dilakukan kalau

merugikan

kepentingan pihak-

pihak tertentu dan harus dicegah

terjadinya berbagai

bentuk monopoli dan

monopsoni.

8. UU No. 9 Tahun 1995

tentang Usaha Kecil

UU ini menyatakan

pemerintah harus

menjaga iklim usaha

dalam kaitannya

dengan persaingan

dengan membuat

peraturan-peraturan

yang diperlukan.

Untuk melindungi

usaha kecil,

pemerintah juga harus

mencegah

pembentukan struktur

pasar yang mengarah

pada pembentukan

monopoli, oligopoli,

dan monopsoni.

9. UU No. 8 Tahun 1995

tentang Pasar Modal

Dalam Pasal 10 UU

No. 8 Tahun 1995 
melarang adanya

ketentuan yang

menghambat adanya persaingan sehat dalam pasar modal.

10. PP No. 70 Tahun 1992 tentang Bank Umum Pada pasal 15 ayat 1 disebutkan, merger dan konsolidasi hanya dapat dilakukan setelah ada izin dari Menteri Keuangan.

11. PP No. 27 Tahun 1998 tentang Penggabungan, Peleburan, dan Pengambilalihan Perseroan Terbatas Dalam Pasal 4 disebutkan bahwa penggabungan, peleburan, dan pengambilalihan perusahaan, hanya dapat dilakukan dengan memerhatikan kepentingan masyarakat dan persaingan usaha.

Apabila substansi hukum meliputi perangkat perundangundangan, maka substansi hukum yang dimaksudkan di sini adalah UU No. 5 Tahun 1999. Setelah 17 tahun diberlakukan ternyata UU tersebut belum cukup efektif dalam menciptakan persaingan usaha yang sehat di Indonesia. Apabila dilihat dari substansi UU tersebut, ternyata terdapat beberapa pasal yang melemahkan kinerja Komisi Pengawas Persaingan Usaha (KPPU). Berikut ini adalah beberapa pasal yang perlu direvisi secepatnya sebagai wujud politik hukum persaingan usaha di Indonesia yang lebih baik dalam menciptakan persaingan usaha yang sehat yaitu :

1. Pasal 41 ayat 1 UU No. 5 Tahun 1999 menyatakan bahwa pelaku usaha dan atau pihak lain yang 
diperiksa

wajib

menyerahkan alat bukti

yang diperlukan dalam

penyelidikan dan atau

pemeriksaan. Lantas,

muncul pertanyaan di

benak saya. Apakah

mungkin pelaku usaha

dan atau pihak lain yang

diduga melakukan

monopoli atau persaingan

usaha tidak sehat mau

untuk menyerahkan alat

bukti yang diperlukan

dalam penyelidikan dan

pemeriksaan tersebut dan

bagaimana kalau

seandainya ada pelaku

usaha atau pihak lain

tidak mau menyerahkan

alat bukti yang diperlukan

dalam penyelidikan dan

atau pemeriksaan

tersebut, apakah ada

konsekuensi hukum bagi

mereka?

Oleh karena itu, saya

menyarankan pasal tersebut direvisi dengan

"Komisi Pengawas

Persaingan Usaha

(KPPU) berwenang untuk

melakukan penyitaan

terhadap alat bukti yang

diperlukan dalam

penyelidikan atau

pemeriksaan terhadap

pelaku usaha dan atau

pihak lain yang diduga

melakukan praktek

monopoli dan atau

persaingan usaha tidak

sehat".

2. Pasal 41 ayat 2 UU No. 5

Tahun 1999 menyatakan

bahwa pelaku usaha

dilarang menolak

diperiksa, menolak

memberikan informasi

yang diperlukan dalam

penyelidikan dan

pemeriksaan, atau

menghambat proses

penyelidikan dan atau

pemeriksaan. Dalam

Pasal 41 ayat 3 UU No. 5 
Tahun 1999 dinyatakan

bahwa pelanggaran terhadap ketentuan ayat (2), oleh Komisi diserahkan kepada penyidik untuk dilakukan penyidikan sesuai dengan ketentuan yang berlaku. Lantas, muncul pertanyaan kembali yaitu apabila situasi tersebut terjadi, adakah akibat hukum yang ditentukan dalam penjelasan ayat ke 3 tersebut karena yang diserahkan oleh Komisi pada penyidik bukan hanya perbuatan atau tindak pidana sebagaimana dimaksud ayat (2), tetapi juga termasuk pokok perkara yang sedang diselidiki dan diperiksa oleh Komisi.

Menurut hemat saya, pemaksaan pelaksanaan kewajiban melalui penyidik tidak berakibat melancarkan pemeriksaan oleh Komisi. Akan tetapi, berakibat penyerahan pokok perkara yang sedang diselidiki kepada penyidik ke luar dari jangkauan Komisi. Penanganan selanjutnya oleh penyidik dan peradilan umum kemungkinan besar berarti tidak dapat dilakukan lagi tindakan administratif karena tidak lagi ditangani oleh Komisi dan terbatas pada pidana pokok dan pidana tambahan, sedangkan tidak semua pelanggaran ketentuan UU tersebut yang dapat dikenakan pidana pokok. Misalnya, Pasal 1-3, Pasal 10-13, dan Pasal 29. Mungkin ini adalah suatu kesalahan atau mungkin memang 
demikian dikehendaki

oleh sang pembuat Undang-Undang (DPR)?

Oleh karena itu, saya menyarankan Pasal 41 perlu adanya tambahan pada ayat (4) yang menyatakan bahwa “Apabila Komisi menyerahkan perkara ini kepada penyidik namun perbuatan pelaku usaha tidak dapat dijerat dengan pidana pokok dan pidana tambahan maka Komisi dapat memberikan sanksi administratif sesuai dengan ketentuan Undang-Undang ini”.

3. Pasal 46 ayat 1 UU No. 5 Tahun 1999 menyebutkan bahwa apabila tidak terdapat keberatan, putusan Komisi sebagaimana dimaksud dalam Pasal 43 ayat (3) telah mempunyai kekuatan hukum yang tetap. Sementara menurut Pasal 46 ayat 2 UU No. 5 Tahun 1999 disebutkan bahwa putusan Komisi sebagaimana dimaksud dalam ayat (1) dimintakan penetapan eksekusi kepada Pengadilan Negeri. Lantas, timbul permasalahan karena ketentuan tentang tata cara eksekusi berakhir di Pasal 46 ayat (2) saja tanpa ketentuan lebih lanjut hukum acara apa yang akan diberlakukan, petunjuk lebih lanjut siapa yang akan menjalankan eksekusi tersebut dan melalui sarana pelaksanaan yang seperti apa?

Oleh karena itulah, saya menyarankan Pasal 46 perlu direvisi dengan tambahan pada ayat (3) yang menyebutkan bahwa "Hukum acara yang 
berlaku di Komisi adalah

hukum acara perdata

kecuali ditentukan lain

oleh undang-undang" dan

tambahan pada ayat (4)

yang menyatakan bahwa

"Putusan Komisi yang

sudah

dimintakan

penetapan eksekusi

kepada Pengadilan Negeri

dilaksanakan menurut

aturan yang biasa

dijalankan pada suatu

putusan perdata". Jadi,

dengan adanya tambahan

pada ayat (3) dan (4)

Pasal 46 UU No. 5 Tahun

1999 maka akan jelas

menurut aturan acara apa

dan siapa yang

melaksanakannya

sehingga

tidak

menimbulkan

permasalahan

di

kemudian hari.

4. Berdasarkan ketentuan

Pasal 47 UU No. 5 Tahun

1999, wewenang untuk menjatuhkan

sanksi

berupa

tindakan

administratif oleh Komisi

tersebut dibagi menjadi :

a. Perintah untuk

menghentikan

sesuatu, dan

b. Penetapan pembatalan sesuatu, sesuai dengan sifat ketentuan yang dilanggar.

Menurut hemat saya, Komisi bukan hanya tidak dibekali dengan ketentuan efektif untuk

melaksanakan tindakan administratif tersebut secara paksa, tetapi juga tidak ada sanksi efektif terhadap tidak dipenuhi isi tindakan administratif oleh Komisi. Hal inilah yang membuat Putusan Komisi seolah-olah tidak mempunyai akibat hukum dan terkesan seperti macan di atas kertas karena tidak dapat 
dilaksanakan secara paksa terhadap pelaku usaha dan berhubung tidak ada sanksi efektif apabila Komisi tidak memenuhi isi tindakan administratif maka Komisi terkesan lepas tangan setelah memutus perkara di persidangan tanpa bertanggung jawab untuk melaksanakan hasil putusan tersebut.

Oleh karena itu, saya menyarankan Pasal 47 (1) UU No. 5 Tahun 1999 perlu adanya tambahan pada ayat (3) yang menyatakan bahwa "Sanksi administratif yang diputuskan oleh Komisi dapat dilaksanakan secara paksa terhadap pihak yang kalah di persidangan" dan tambahan pada ayat (4) yang menyatakan bahwa "Apabila Komisi tidak melaksanakan putusannya yang berupa sanksi administratif selambatlambatnya 90 hari (3 bulan) maka demi hukum sanksi administratif tersebut dianggap tidak pernah ada".

5. Pasal 47 ayat 2 huruf $g$ menyatakan bahwa pengenaan denda serendah-rendahnya $\quad R p$ 1.000.000.000,00 (satu milyar rupiah) dan setinggi-tingginya $\quad R p$ 25.000.000.000,00 (dua puluh lima milyar rupiah) perlu direvisi karena apabila kerugian yang ditimbulkan itu jumlahnya bisa sampai trilyunan tentu negara akan sangat dirugikan sekali dengan ambang batas maksimal pengenaan denda yang hanya sebesar Rp. 25.000.000.000,00 (dua 
puluh lima milyar rupiah). Sebut saja, kasus monopoli yang dilakukan oleh PT. Temasek dimana keuntungan yang diperoleh dari tindakan monopoli tersebut mencapai lebih kurang 7 trilyun. Oleh karena itu, ketentuan tersebut perlu direvisi dengan "Pengenaan denda terhadap pelaku usaha dan atau pihak lain yang melakukan praktek monopoli dan atau persaingan usaha tidak sehat adalah sebesar 50\% dari keuntungan yang diperolehnya atas perbuatan tersebut". Jadi, apabila keuntungan yang diperoleh pelaku usaha atau pihak lain atas praktek monopoli dan atau persaingan usaha tidak sehat itu nilainya mencapai 100 milyar rupiah maka denda yang akan dikenakan terhadap pelaku usaha atau pihak lain tersebut adalah sebesar 50 milyar rupiah. Harapannya adalah pelaku usaha dan atau pihak lain itu tidak berani untuk melakukan praktek monopoli dan atau persaingan usaha tidak sehat menginat dendanya yang begitu besar. Dengan begitu diharapkan akan tercipta suatu persaingan usaha yang sehat di Indonesia.

\section{KESIMPULAN DAN}

SARAN

\subsection{Kesimpulan}

1. Undang-Undang Nomor 5 Tahun 1999 tentang Larangan Praktek Monopoli dan Persaingan Usaha Tidak Sehat merupakan implementasi dari politik 
hukum persaingan usaha di Indonesia. Politik hukum persaingan usaha di Indonesia pada prinsipnya tergantung political will dari anggota Dewan Perwakilan Rakyat (DPR) selaku legislatif bersama dengan Pemerintah selaku eksekutif dalam membuat UndangUndang.

2. Sebab UndangUndang Nomor 5 Tahun 1999 tentang Larangan Praktek Monopoli dan Persaingan Usaha Tidak Sehat belum cukup efektif dalam menciptakan persaingan usaha yang sehat di Indonesia dikarenakan dalam substansi UU tersebut masih terdapat kelemahan dalam beberapa pasal yang membuat kinerja Komisi Pengawas Persaingan Usaha (KPPU) menjadi tidak maksimal.

\subsection{Saran}

1. Hendaknya anggota DPR sebagai legislator bersama dengan Pemerintah bersinergi membuat UU yang betulbetul bisa mencegah dan menanggulangi terjadinya praktek monopoli dan persaingan usaha tidak sehat di Indonesia.

2. Perlu ada revisi secepatnya terhadap beberapa pasal yang terdapat dalam UndangUndang Nomor 5 Tahun 1999 tentang Larangan Praktek Monopoli dan Persaingan Usaha Tidak Sehat agar bisa menciptakan persaingan usaha yang sehat di Indonesia. 


\section{DAFTAR PUSTAKA}

Buku-buku, Jurnal, Makalah, dan

\section{Majalah}

Abdul Hakim Garuda Nusantara, "Politik Hukum Nasional", makalah disampaikan pada Karya latihan Bantuan Hukum (Kalabahu), diselenggarakan Yayasan LBH Indonesia dan LBH Surabaya, September 1985.

Abdul Latif, dkk., Politik Hukum, Jakarta: Sinar Grafika, 2010, Cet. I.

Bernard L. Tanya, Politik Hukum Agenda Kepentingan Bersama, Yogyakarta: Genta Publishing, 2011, Cet.I.

C.F.G. Sunaryati Hartono, Politik Hukum Menuju Satu Sistem Hukum Nasional, Bandung: Alumni, 1991, Cet.I.

Imam Syaukani, dkk., Dasar-dasar Politik Hukum, Jakarta: Rajawali Pers, 2008, Ed.1.

Moh. Mahfud MD, Politik Hukum di Indonesia, Jakarta: Rajawali Pers, 2011, Cet. IV.
Mukti Fajar ND dan Yulianto Achmad, Dualisme Penelitian Hukum Normatif dan Empiris, Yogyakarta: Pustaka Pelajar, 2010.

Mustafa Kamal Rokan, Hukum Persaingan Usaha (Teori dan Praktiknya di Indonesia), Jakarta: Rajawali Pers, 2010.

Padmo Wahjono, Indonesia Negara Berdasarkan Atas Hukum, Jakarta: Ghalia Indonesia, 1986, Cet. II.

Peter Mahmud Marzuki, Penelitian Hukum, Jakarta: Kencana, 2005.

Satjipto Rahardjo, Ilmu Hukum, Bandung: Citra Aditya Bakti, 1991, Cet. III.

Soedarto, "Perkembangan Ilmu Hukum dan Politik Hukum," dalam majalah Hukum dan Keadilan, No. 5 Tahun VII, Januari-Februari 1979.

Soerjono Soekanto, Pengantar Penelitian Hukum, Jakarta: UI Press, 1986.

Soerjono Soekanto dan Sri Mamudji, Penelitian Hukum Normatif, Jakarta: Rajawali Pers, 2011. 
Susanti Adi Nugroho, Pengaturan

Hukum Persaingan Usaha di

Indonesia,

Jakarta:

Pulitbang/Diklat Mahkamah

Agung, 2001.

Sutandyo Wigyosubroto, Hukum:

Paradigma, Metode dan

Dinamika Masalahnya, Jakarta:

Huma, 2002.

Suyud Margono, Hukum Anti

Monopoli, Jakarta: Sinar

Grafika, 2009, Cet.I.

Teuku Mohammad Radhie,

"Pembaruan dan Politik

Hukum dalam Rangka

Pembangunan Nasional,"

dalam majalah Prisma No. 6

Tahun II, Desember 1973.

\section{Peraturan Perundang-Undangan}

Ketetapan MPR RI No. IV/MPR/1973

tentang GBHN bidang

Pembangunan Ekonomi.

Ketetapan MPR RI No. IV/MPR/1978 tentang GBHN pada bidang Pembangunan Ekonomi pada Sub Bidang Usaha Swasta dan Usaha Golongan Ekonomi Lemah.

Ketetapan MPR RI No. II/MPR/1983 tentang GBHN pada Bidang
Pembangunan Ekonomi Sub Bidang Usaha Swasta Nasional dan Usaha Golongan Ekonomi Lemah.

Ketetapan MPR No. II/MPR/1988 tentang GBHN pada Bidang Pembangunan Ekonomi Sub Bidang Dunia Usaha Nasional.

Ketetapan MPR RI No. II/MPR/1993 tentang GBHN pada Bidang Pembangunan Ekonomi Sub Bidang Usaha Nasional.

Ketetapan MPR RI No. IV/MPR/1999 tentang GBHN pada Kondisi Umum.

Kitab Undang-Undang Hukum Pidana (KUHP).

Kitab Undang-Undang Hukum

Perdata (KUHPerdata).

UU No. 5 Tahun 1960 tentang

Peraturan Dasar Pokok-Pokok

Agraria.

UU No. 5 Tahun 1984 tentang Perindustrian.

UU No. 19 Tahun 1992 tentang Merek.

UU No. 1 Tahun 1995 tentang Perseroan Terbatas.

UU No. 9 Tahun 1995 tentang Usaha Kecil. 
UU No. 8 Tahun 1995 tentang Pasar

Modal.

Undang-Undang Nomor 5 Tahun

1999 tentang Larangan Praktek

Monopoli dan Persaingan

Usaha Tidak Sehat.

PP No. 70 Tahun 1992 tentang Bank

Umum.

PP No. 27 Tahun 1998 tentang

Penggabungan, Peleburan, dan

Pengambilalihan Perseroan

Terbatas.

\section{Data Elektronik}

https://balianzahab.wordpress.com/m

akalah-hukum/politik-

hukum/apa-politik-hukum-itu/,

diakses terakhir kali tanggal 7

Maret 2017 jam 08:00 WIB. 